\title{
THE EFFECT OF BOARD OF DIRECTOR, BOARD OF COMMISSIONER AND AUDIT COMMITTEE ON VALUE OF FIRM TO ISLAMIC SOCIAL REPORTING AS A MEDIATING VARIABLE
}

\author{
Rika Lidyah ${ }^{1)}$, Amri Amir'), Syahmardi Yacob ${ }^{3)}$, Sri Rahayu ${ }^{4)}$ \\ ${ }^{1)}$ Faculty of Economics And Islamic Business, UIN Raden Fatah Palembang, Palembang Indonesia \\ ${ }^{2,3,4)}$ Fakultas Ekonomi, Universitas Jambi, Jambi Indonesia \\ Corresponding email: rikalidyah_uin@radenfatah.ac.id
}

\begin{abstract}
s
This research aim to analyze the effect of number of Board of Directors, number of Commissioners and audit committee of the company with the Islamic social reporting as mediation variables. This research was conducted on the basic and chemical industrial enterprises registered in the ISSI. The research found that the number of Board of Director, number of Commissioners and audit committee of the value of firm affects. The number of Board of Director of Islamic have effect on social reporting, whereas number of Commissioner and audit committee do not have effect to the Islamic social reporting. Islamic social reporting can mediate all the variables (the number of Commissioner and the Board of Director, the audit committee of the company).
\end{abstract}

Keywords: Board of Director, Board of Commissioner, Audit Committee, Value of Firm, Islamic Social Reporting

\section{Introduction}

The firm value is affected by several factors such as good corporate governance and profitability. Corporate governance is the relationship between the various parties within company that determines between direction and performance of the company. The existence of a direction and a good performance from the company will demonstrate company success, raising the value of firm.

The process of maximizing the value of firm allows the appearance of agency conflict in which company managers (agent) have an interest conflicting with the main goal of the company and often overlook the interests of the shareholders (principal). This agency conflict will add cost (agency cost) for the enterprises and effect on stock prices thus lowering the value of the company.

Corporate governance is a concept that is expected to serve as a tool to ensure fairness, transparency, accountability, and responsibility from the insider of the company. This mechanism is made to ensure the protection is good for the company's stakeholders so that the problems of the Agency and the possibility of expropriation (fraud) can be minimized.

In the theory of Stakeholder stated that company survive depends on the support and sought of stakeholders and, so the activity of the company is looking for support. The more powerful stakeholders, the greater the company's effort to adapt. Social disclosure is considered as a medium of communication between the company's stakeholders.

The Board of Commissioners assigned to guarantee the implementation of corporate strategy, overseeing management in manage the company, as well as required the implementation of accountability. The Board of Commissioners is an important factor from the mechanism of corporate governance.

Audit committee has independent oversight in the process controls and risks. The audit committee is formed to run the task in assisting the Board of Commissioners are responsible to provide information to stakeholders in the form of Islamic social reporting disclosure.

Greater number of the audit committee of the company then owned by the management company will have a higher pressure to express their Islamic Social Reporting in annual report of the company. Audit committee as one of driving mechanism in corporate governance that could affect the disclosure of corporate social responsibility.

Noor Laila (2011), found that there is an influence of the Board of Director and Commissioners of the company. Frysa Praditha Purwaningtyas (2011) shows the presence of effect between the number of Board of Director of the company. Fika Fiadicha, 2016; Kilat Liliani Nintyas, 2014, shows there is no influence between the number of Board of Director and Commissioners of the company.

Dedi Yansyah (2018) research indicates there is no effect between the number of Commissioners of the company. M. Ikhsan Full (2016) and Rahayu Tesdha (2013) research showed positive influence among Islamic Social Reporting (ISR) to the value of firm. Sartika Handayani Kansar (2016) indicates there is no influence between Islamic social reporting (ISR) to the firm value. 
Desy Dianitami (2016) shows there are influences between the number of Board of directors to the Islamic Social Reporting (ISR). Vina Septiana Permatasari (2015) research which showed negative influence between Board of directors to the Islamic Social Reporting. Wardatul baidok and Fitrisia Septiarini Dina (2016) and Winda Siti Hardiatma (2017) shows the presence of influence between the number of Commissioners to the Islamic social reporting (ISR). Mariska Nanda Savira (2015) showed a negative effect between the number of Commissioners to the Islamic social reporting (ISR).

Based on description and previous research above, the hypotheses in this reserarch is:

$\mathrm{H}_{1} \quad$ : Number of Board of Directors has significant effect Islamic Social Reporting (ISR)

$\mathrm{H}_{2}$ : The number of Commissioners has significanlyt effect Islamic Social Reporting (ISR).

$\mathrm{H}_{3}$ : Audit Committee has significant effect to Islamic Social Reporting (ISR)

$\mathrm{H}_{4} \quad$ : Number of Board of Director has significantly effect to Firm Value

$\mathrm{H}_{5}$ : The number of Commissioners has significant effect to Firm Value

$\mathrm{H}_{6} \quad$ : The Audit Committee has significant effect to Firm Value

$\mathrm{H}_{7} \quad$ : Islamic Social Reporting (ISR) has significant positive effect to Value of Firm

$\mathrm{H}_{8} \quad$ : Islamic Social Reporting (ISR) mediate effect number of Board of Directors on Value of Firm

$\mathrm{H}_{9} \quad$ : Islamic Social Reporting (ISR) mediate effect number of Commissioners on Value of Firm

$\mathrm{H}_{10}$ : Islamic Social Reporting (ISR) mediate effect Audit Committee on Value of Firm

Figure 1

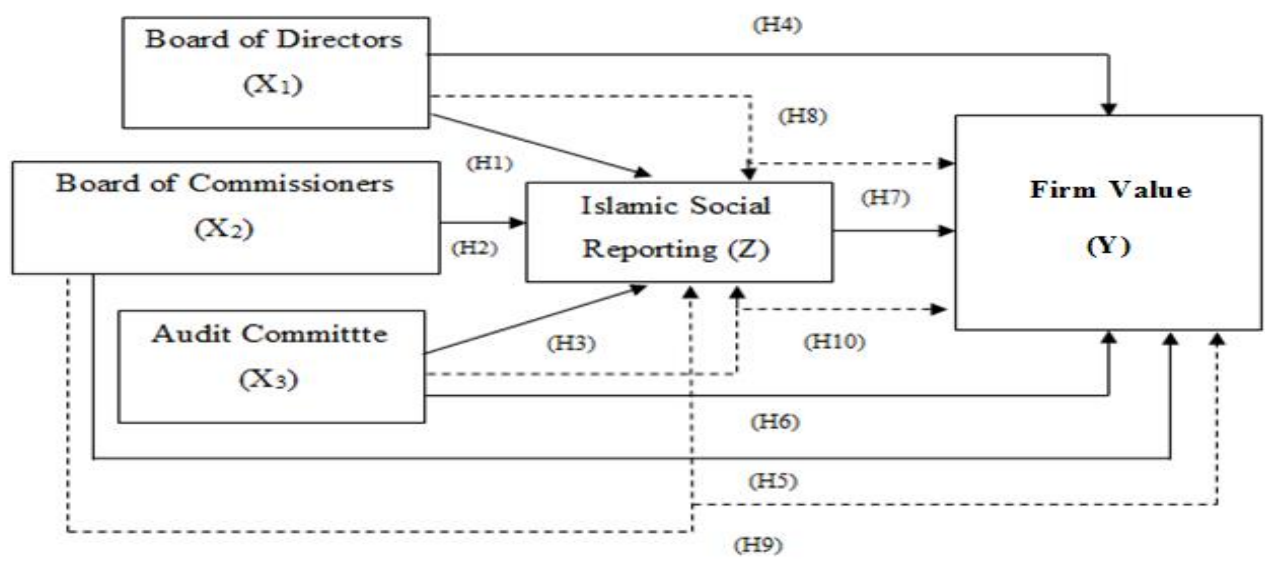

Source: developed for this study (2018)

Figure 1

Research Model

\section{Methods}

This research population is basic industry and chemicals sector enterprises registered in Indeks Saham Syariah Indonesia (ISSI) in 2010 - 2017, the required data-related variables were measured during the period of 2010-2017.

\section{Result and Discussions}

Data processed by using multiple regression analysis using two equations .

Table 1. The Test Of Hypothesis

\begin{tabular}{lllcc}
\hline & & Equation I & Equation II \\
\hline \multirow{3}{*}{ F test } & F & 17.273 & 2.906 \\
\cline { 2 - 4 } & Sig & .000 & .037 \\
\cline { 2 - 4 } & Sig. The Board of Directors & .036 & .000 \\
\cline { 2 - 4 } T test & Sig. The Commissioners & .439 & .030 \\
\cline { 2 - 4 } & Sig. The Audit Committee & .866 & .000 \\
\cline { 2 - 4 } & Sig. Islamic Social Reporting & & .011 \\
\hline
\end{tabular}

Source: processed data,2018.

Based on the F test result from table above, the calculated F value is 17.273 with Sig. 0,000 in equation I and the calculated F value is 2.906 with Sig. 0.037 because value of the probability of significance is smaller than 0.05. Regression model is feasible and correct 


\section{The effect of number of Board of Director to Islamic Social Reporting (ISR).}

The results of the study state that number of board of directors has a positive and significant effect on ISR. This is supported by research conducted by Desy Dianitami (2016) and Andita Putri (2018). The board of directors carries out responsibilities well in the management and interests of the company so that the relationship between stakeholders and company managers (board of directors) will run well in the company's social disclosures. With the existence of corporate social disclosure, the company indirectly adapts to the community and this can add firm value.

\section{The effect of number of Commissioners on Islamic Social Reporting (ISR).}

The results stated that number of board of commissioners had no effect significantly towards ISR. This is supported by previous research conducted by Mariska Nanda Savira (2015), Qoyum, Mutmainah, Setyono, \& Qizam (2017) and Lestari (2013). The board of commissioners is only limited to overseeing ISR disclosures, so that the board of commissioners and ISR disclosures are inefficient so the results of the study state that board of commissioners has no effect to ISR disclosure.

\section{The effect of number of Audit Committee on Islamic Social Reporting (ISR).}

The results of the study stated that audit committee had no significantly effect on Islamic Social Reporting (ISR). This is similar to previous researchers conducted by Hartawati, Sulindawati, \& Kurniawan (2017) and Baidok \& Septiarini (2016), jannah and Asrori (2016) and Mahardika and Rizal (2017). that the size of the audit committee in the company does not affect the quality of disclosure of company information. The audit committee has responsibilities in three areas, namely financial statements, corporate governance and corporate supervision. The influence of the audit committee on ISR disclosure is likely because the audit committee is more responsible in corporate governance and responsibility in financial statements than responsibility in disclosure of social information, so the audit committee does not guarantee that the supervision of management is fraudulent in disclosure social responsibility will work effectively.

\section{The effect of Board of Directors on Value of Firm}

The results of this study state that the number of boards of directors has a positive and significant influence on firm value. This is supported by research conducted by Noor Laila (2011), Frysa Praditha Purwaningtyas (2011), Kristie Onasis and Robin (2016). With the board of directors in the company, more and more councils in the company will provide a form of supervision of company performance the better, with good and controlled company performance, it will produce good profitability and later will be able to increase the company's stock price and firm value will also increase.

\section{The effect of Number of Board of Commissioners on Value of Firm}

The results of this study state that number of boards of commissioner has a positive and significant influence on value of firm. This is supported by research conducted by Noor Laila (2011), Fika Fiadicha (2016) and Kristie Onasis and Robin (2016). The size of board of commissioners is not major determinant effectiveness of supervision from company management, because board of commissioners is the core of corporate governance that is assigned to guarantee the company's strategy, oversee managers in manage the company, and required accountability. So that board of commissioners is very influential on the firm value, with the board of commissioners biased to oversee the implementation of the company in achieving company goals that have an impact on increasing the valueof firm.

\section{The Effect of Audit Committee on Firm Value}

The results of this study state that audit committee has significant positive influence to company value. This is supported by research of Kristie Onasis and Robin (2016), Obradovich and Gill (2013). The presence of audit committee that oversees performance of the board of commissioners and improves the quality of information flow between shareholders and managers so as to help reduce agency problems and increase firm value (Obradovich and Gill, 2013). Audit committee has role in overseeing the company's financial reporting process that has been compiled through an audit process with the integrity and objectivity of the auditor. The audit committee will effectively increasing credibility of financial statement and assist board of commissioners to gain trust from shareholders. In terms of financial data manipulation, the audit committee contributes to helping examine data on financial statements so that they can be accounted for. With the presentation of clear and transparent financial information will reduce information that is wrong and increase the firm value(Rouf, 2011).

\section{The effect of Islamic Social Reporting (ISR) on Value of Firm.}

The results of this study state that Islamic Social Reporting (ISR) has significant positive influence on value of firm. This is supported by research conducted by m. Ikhsan Full (2016) and Rahayu Tesdha (2013). With the Islamic Social Reporting (ISR) as a corporate strategy to satisfy the desires of stakeholders, both the Islamic Social Reporting (ISR) disclosure and company stakeholders will be more satisfied so it will give full 
support to the company over all disclosures of such social activity because by doing social disclosure such as Islamic Social Reporting (ISR) will raise level of social and financial performance so that the company will get profits and indirectly be associated with an increase in the firm value

Causal Step Strategy

Causal Step Strategy (The Effect of Islamic Social Reporting (ISR) between Number of Board of Directors on Value of Firm)

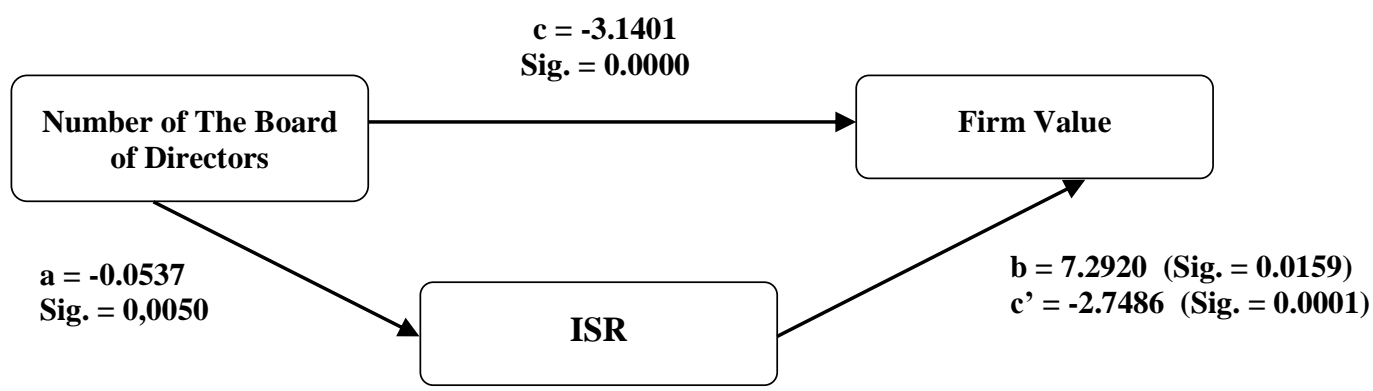

Source: Secondary processed data by SPSS 22, 2018

$\mathrm{Y}=\beta$ Number of The Board of Directors $+\beta \mathrm{ISR}+\mathrm{e}$

This shows that Islamic Social Reporting mediates between the effect of the number of board of directors on firm value.

Causal Step Strategy (The Effect of Islamic Social Reporting (ISR) between Number of Board of Commissioners on Value of Firm)

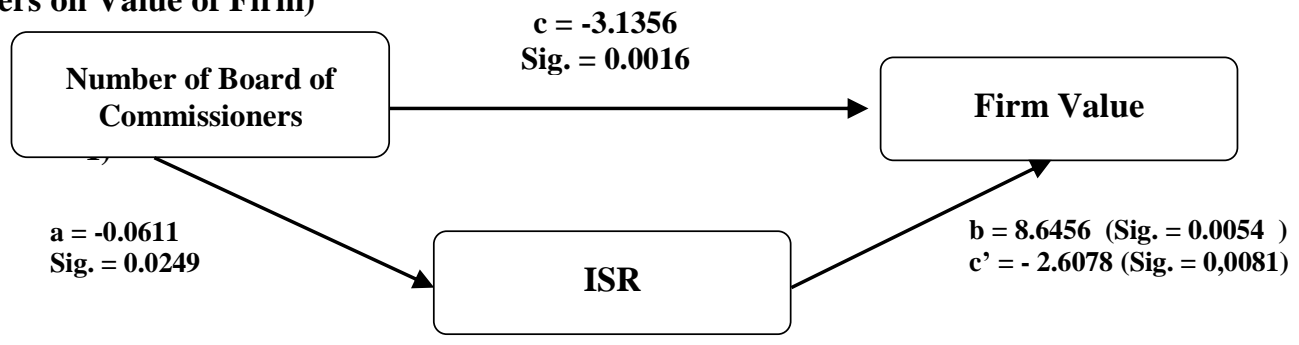

Source: Secondary processed data by SPSS 22, 2018

$\mathrm{Y}=\beta$ The Number of Board of Commissioners $+\beta \mathrm{ISR}+\mathrm{e}$

This shows that Islamic Social Reporting mediates between the effect of the number of commissioners on firm value.

Causal Step Strategy (The Effect Islamic Social Reporting (ISR) between Number of Audit Committee on Firm Value)

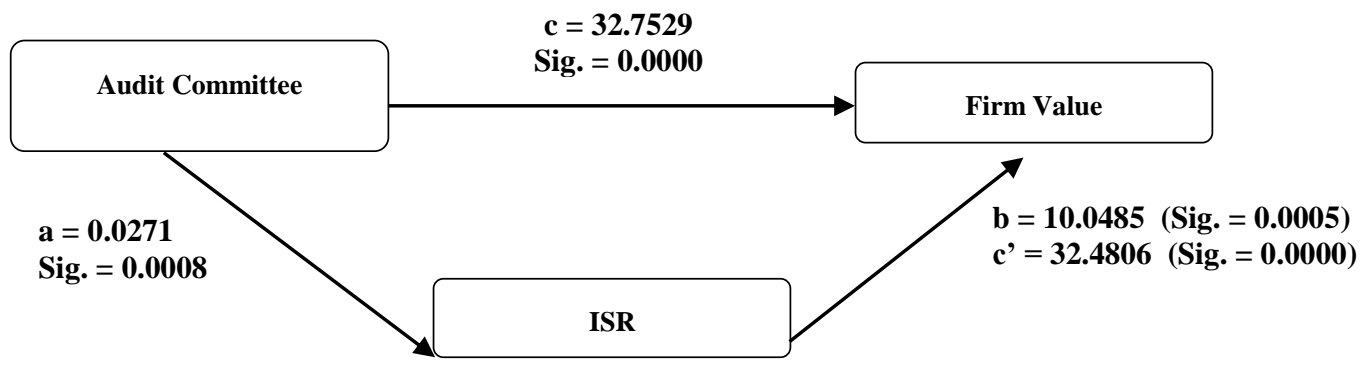

Source: Secondary processed data by SPSS 22, 2018

$$
\mathrm{Y}=\beta \text { Audit Committee }+\beta \mathrm{ISR}+\mathrm{e}
$$

This shows that Islamic Social Reporting mediates between the effect of number of audit committee on value of firm. 


\section{Conclusions}

Based on data analysis result using path analysis as described previously with the following results: the number of board of directors has positive and significantly effect on ISR, number of board of commissioner has no effect and is not significant on ISR, number of Board of Directors has significant positive effect to firm value, number of board of commissioners positive and significantly effect on firm value, Islamic Social Reporting (ISR) has positive and significantly effect on firm value, Islamic Social Reporting (ISR) mediate effect of board of directors on firm value and Islamic Social Reporting (ISR) mediate effect number of commissioners on value of firm.

\section{References}

Al Farisi, J. R. (2015). Pengaruh Mekanisme Gcg, Investment Account Holder Dan Ukuran Perusahaan Terhadap Pengungkapan Islamic Social Reporting Pada Bank Umum Syariah Di Indonesia (Doctoral dissertation, Universitas Negeri Semarang).

Azheri, B. (2011). Corporate social responsibility: Dari voluntary menjadi mandatory. RajaGrafindo Persada.

Baidok, W., \& Septiarini, D. F. (2017). Pengaruh Dewan Komisaris, Komposisi Dewan Komisaris Independen, Dewan Pengawas Syariah, Frekuensi Rapat Dewan Komisaris Syariah, Dan Frekuensi Rapat Komite Audit Terhadap Pengungkapan Indeks Islamic Social Reporting Pada Bank Umum Syariah Periode 2010-2014. Jurnal Ekonomi Syariah Teori dan Terapan, 3(12), 1020.

Dian, F., \& Lidyah, R. (2014). Pengaruh corporate social responsibility, kepemilikan manajerial dan kepemilikan institusi terhadap nilai perusahaan tambang batu bara yang terdaftar di BEI.

Eiteman, D. K., Stonehill, A. I., \& Moffett, M. H. (2010). Manajemen Keuangan Multinasional, edisi kesebelas jilid 2. Penerbit Erlangga, Jakarta.

Ekananda, M. (2015). Ekonometrika dasar untuk penelitian dibidang ekonomi, sosial dan bisnis. Jakarta: Mitra Wacana Media.

Fiadicha, F. (2016). Pengaruh good corporate governance, corporate social responsibility dan kinerja keuangan terhadap nilai perusahaan. Jurnal akuntansi manajerial, 1(1).

Ghozali, I. (2016). Aplikasi Analisis Multivariete dengan Program IBM SPSS 23, Edisi Delapan. Penerbit Universitas Diponogoro. Semarang.

Haniffa, R. (2002). Social reporting disclosure: an Islamic perspective. Indonesian Management \& Accounting Research, 1(2), 128-146.

Haniffa, R., \& Hudaib, M. (2006). Corporate governance structure and performance of Malaysian listed companies. Journal of Business Finance \& Accounting, 33(7-8), 1034-1062.

Hardiatma, W. S. (2017). Pengaruh Elemen Good Corporate Governance Terhadap Pengungkapan Islamic Social Reporting Pada Perbankan Syariah di Indonesia.

Hartawati, E., Sulindawati, N. L. G. E., Ak, S. E., Kurniawan, P. S., \& ST, M. (2018). Pengaruh Ukuran Perusahaan, Profitabilitas, Kinerja Sosial, Kinerja Lingkungan Dan Komite Audit Terhadap Pengungkapan Islamic Social Reporting (ISR) Pada Perusahaan Yang Terdaftar Di Jakarta Islamic Index (JII) Periode Tahun 2014-2016. JIMAT (Jurnal Ilmiah Mahasiswa Akuntansi) Undiksha, $8(2)$.

Kasmir, (2014). Analisis Laporan Keuangan. PT Raja Grafindo Persada, Jakarta

M Ikhsan, P., H Nashruddin, B., Condro, H. D., Triono, S. P., \& Ag, M. (2017). Pengaruh Islamic Social Reporting Terhadap Nilai Perusahaan Bank Syariah Di Indonesia (Doctoral dissertation, IAIN Surakarta).

Ningtyas, K. L. (2014). Pengaruh Good Corporate Governance Terhadap Nilai Perusahaan (Studi Pada Perusahaan Yang Terdaftar Di Jakarta Islamic Index Tahun 2010-2013). Jurnal Administrasi Bisnis, 17(1).

Laila, N., \& SYAICHU, M. (2011). Analisis Pengaruh Good Corporate Governance terhadap Nilai Perusahaan (Studi Empiris pada Perusahaan Manufaktur yang Terdaftar di Bursa Efek Indonesia Periode 2005-2009) (Doctoral dissertation, Universitas Diponegoro).

Othman, R., \& Thani, A. M. (2010). Islamic social reporting of listed companies in Malaysia. International Business \& Economics Research Journal, 9(4), 135-144.

Othman, R., Thani, A. M., \& Ghani, E. K. (2009). Determinants of Islamic social reporting among top Shariah-approved companies in Bursa Malaysia. Research Journal of International Studies, 12(10), 4-20.

Pardede, R., \& Manurung, R. (2014). Analisis Jalur (Path Analysis): Teori dan Aplikasi dalam Riset Bisnis. Jakarta: Rineka Cipta.

Purwaningtyas, F. P. (2011). Analisis Pengaruh Mekanisme Corporate Governance Terhadap Nilai Perusahaan. Universitas Diponegoro Semarang. 
Qoyum, A., Setyono, J., \& Qizam, I. (2017). The Impact of Good Corporate Governance, Company Size nn Corporate Social Responsibility Disclosure: Case Study of Islamic Banking in Indonesia. Iqtishadia: Jurnal Kajian Ekonomi dan Bisnis Islam STAIN Kudus, 10(1), 103-159.

Regar, M. H. (2000). Dewan komisaris: peranannya sebagai organ perseroan. Bumi Aksara.

Savira, M. N. (2015). Pengaruh Ukuran Perusahaan, Ukuran Dewan Komisaris, Ukuran Dewan Pengawas Syariah, Crossdirectorship, Kepemilikan Manajerial, Dan Kepemilikan Institusional Terhadap Pengungkapan Islamic Social Reporting (ISR) (Doctoral dissertation, UNIVERSITAS NEGERI SEMARANG).

Sugiyono, P. Dr. (2011). Metode Penelitian Kuantitatif, Kualitatif, dan R\&D. Bandung: CV Alfabeta.

Sugiyono, D. R. (2016). Metode Penelitian Administrasi. Bandung, Alfabeta.

Sumardi Surya Brata, (2015). Metodologi Penelitian, Rajawali Pers, Jakarta.

Sutedi, A. (2011). Good corporate governance. Sinar Grafika.

Tesdha Rahayu, (2013). Pengaruh Pengungkapan Islamic Social Reporting Index (Indeks ISR) Terhadap Nilai Perusahaan. (Studi Empiris pada Perusahaan - Perusahaan Industri Dasar dan Kimia yang terdaftar di Daftar Efek Syariah (DES) periode 2010-2011).

Sujarweni, V. W. (2015). Metodologi Penelitian Bisnis \& Ekonomi. Paper Plane. Yogyakarta.

Widjaja, G. (2003). Tanggung Jawab Direksi atas Kepailitan Perseroan. Divisi Buku Perguruan Tinggi, RajaGrafindo Persada.

Zaeni, A. (2014). Hukum Bisnis Prinsip dan Pelaksanaannya di Indonesia. Penerbit PT Raja Grafindo Persada, Jakarta.

\section{Authors' Bibliography}

Rika Lidyah, was born in Palembang, Sumatera Selatan, April $8^{\text {th }}, 1975$. She graduated the bachelor degree from Economic Faculty of Muhammadiyah University in 1999, and master degree from Master of Science of Gadjah Mada University in 2002. She completed the Accountant Profession Education Program at the University of Sriwijaya in the year 2014. Currently, Rika Lidyah on progress to accomplish the doctoral program of Finance Management from Economic Faculty of Jambi University in Jambi. 